\title{
Cymatium parthenopeum parthenopeum (von Salis, 1793) (Mesogastropoda: Ranellidae): A New Bioindicator of Organotin Compounds Contamination?
}

\author{
M. B. Costa, ${ }^{1}$ M. B. P. Otegui, ${ }^{1}$ D. C. Barbiero ${ }^{1} \&$ M. A. Fernandez ${ }^{2 *}$ \\ I Universidade Federal do Espírito Santo (UFES), Centro de Ciências Humanas e Naturais, Departamento de Ciências \\ Biológicas, Laboratório de Malacologia, Av. Marechal Campos, 1468, Maruípe, CEP 29040-090, Vitória, ES, Brazil \\ ${ }^{2}$ Uni \\ Universidade Estadual do Rio de Janeiro (UERJ), Programa de Ecotoxicologia Marinha, Departamento de Oceanografia, \\ Rua São Francisco Xavier, 524, $4^{\underline{0}}$ andar, sala 4018E, Maracanã, CEP 20550-013, Rio de Janeiro, RJ, Brazil
}

(Received November 14, 2007; Accepted May 30, 2008)

\begin{abstract}
This work reports the occurrence of imposex in the mesogastropod Cymatium parthenopeum parthenopeum in the coast of Espírito Santo (Southeastern Brazil) and evaluates the possible use of this species as a bioindicator of organotins (OTs) contamination. A total of 53 adult specimens were sampled at Formosa beach nearby the Vitoria main marina, which is a critical area for this kind of contamination. The animals were analyzed using a non-destructive protocol and a sub-sample of 7 animals (6 imposexed females and 1 control male) were dissected for a more detailed observation. Imposex development was observed in 39 out of 44 sampled females. Imposexed females showed pre-penis and penis development, but a vas deferens development similar to that of the males was not observed. No sign of sterility was found. A comparison with data from other species in this area indicates that C. parthenopeum parthenopeum, although less sensitive to imposex induction, can be used as biological indicator of OTs contamination.
\end{abstract}

Key words: Antifoulings, bioindicators, imposex, mesogastropods

\section{RESUMO}

Imposex em Cymatium parthenopeum parthenopeum (von Salis, 1793)

(Mesogastropoda: Ranellidae): um novo bioindicador de compostos organoestânicos?

Este estudo reporta a ocorrência de imposex no mesogastrópode Cymatium parthenopeum parthenopeum na costa do Espírito Santo (Sudeste do Brasil) e avalia o possível uso dessa espécie como bioindicador de contaminação por organoestânicos (OTs). Um total de 53 exemplares adultos foi amostrado na Praia Formosa, próxima à principal marina de Vitória, área crítica para esse tipo de contaminação. Os exemplares foram analisados de forma não-destrutiva, e uma subamostra de 7 animais (6 fêmeas imposexadas e 1 macho para controle) foi dissecada e analisada detalhadamente pelo método convencional. $\mathrm{O}$ desenvolvimento do imposex foi observado em 39 de 44 fêmeas amostradas. As fêmeas apresentaram desenvolvimento de prépênis e pênis, mas o desenvolvimento de vaso deferente similar ao do macho não foi observado. Não foram observados sinais de esterilização. A comparação com dados de outras espécies na região sugere que essa espécie, embora menos sensível à indução de imposex, pode ser considerada como bioindicadora para contaminação por OTs.

Palavras-chave: antiincrustantes, bioindicadores, imposex, mesogastrópode.

Corresponding author: Mercia Barcellos da Costa, e-mail: merciabc@gmail.com. 


\section{INTRODUCTION}

The aquatic environment is the ultimate destination for almost all urban, industrial and agricultural wastes in coastal areas. Among xenobiotic chemicals, organotin compounds (OTs) as tributyltin (TBT) and triphenyltin (TPT) have been used as biocides in agriculture (Champ \& Seligman, 1996), as stabilizers in the manufacture of polyvinylchoride (Fent, 1996) and wood preservatives (Bennett, 1996). These two compounds were also widely employed as biocides in marine antifouling paints to prevent the fixation of fouling organisms such as seaweeds or barnacles in ships hulls and even in cooling systems (Fent, 1996).

TBT has been described as the most toxic compound deliberately introduced in the aquatic environment (Goldberg, 1986) and has caused great concern due to the deleterious effects on non-target organisms (Alzieu, 1998; WWF, 2006). The possibility of transfering through marine food chains has been detected in marine mammals and birds (Tanabe, 1999; Guruge et al., 1997; Le et al., 1999), including in some instances the possibility of reaching human populations (Chien et al., 2002; Fernandez et al., 2005a).

The use of OTs is controlled in many countries, and a global ban on their use was scheduled by IMO (International Maritime Organization) to January, 2003. However, the required number of 25 countries with $25 \%$ of the world merchant fleet was reached only in late 2007 (26 countries, $38.13 \%$ world fleet by December, 31, 2007, www.imo.org) and consequently, the ban is not in force yet. Moreover, TBT-based antifouling paints are still widely used in developing countries (Shi et al., 2005; WWF, 2006).

Among marine animals, gastropods present the greatest potential for OTs bioaccumulation because of their limited capacity to metabolize and eliminate such compounds. They are, therefore, excellent bioindicators of organotins pollution in the marine ecosystems, which can be evaluated by the development of imposex.

This syndrome has already been described in more than 170 species of gastropods (Matthiessen \& Gibbs, 1998; Shi et al., 2005), including the development of a penis and/or vas deferens which can led to the disappearance of species due to sterilization or death of the affected females, in local and even regional scale (Gibbs \& Bryan, 1986). As imposex shows a dose-dependent response, it has been used as biomarker for different levels of contamination for almost 20 years (Gibbs \& Bryan, 1994; Fernandez et al., 2007).

Although the majority of imposex studies worldwide (Gibbs \& Bryan, 1987; Gooding et al., 1999; Gibson \& Wilson, 2003) and in Brazil (Fernandez, 2001; Fernandez et al., 2002; 2005b, 2007; Pinheiro et al., 2006; Quadros, 2004; Castro, 2005; Castro et al., 2007; Camillo et al., 2004; Caetano \& Absalão, 2002; Castro et al., 2004) have used neogastropod species, mesogastropods have been also used despite being less sensitive in most cases (Mensink et al., 2002; Castro et al., 2003) ${ }^{1}$.

During previous investigations about clams and gastropods populations, the absence of neogastropods such as Leucozonia nassa (Gemelin,1791), Stramonita haemastoma (Linnaeus, 1767) and Thais deltoidea (Lamarck, 1822) was observed in some areas next ports and marinas of Vitória city. Simultaneously, it was noticed the presence of many mesogastropods populations such as Littorina flava King \& Broderip, 1832, Cerithium atratum (Born, 1778), Crepidula sp. and specifically $C$. parthenopeum parthenopeum (von Salis, 1793), a benthic carnivorous specie common in the tropical Atlantic, with an extensive geographic distribution (Rios, 1994).

This observation led us to investigate if $C$. parthenopeum parthenopeum can be used as a new bioindicator and, consequently, evidence that the absence of neogastropods could have been caused by exposure to OTs. Thus, the present study examined the occurrence of imposex in $C$. parthenopeum parthenopeum in a beach near to an important marina of Vitória (Espírito Santo Yacht Club).

\section{MATERIALAND METHODS}

Adult individuals $(\mathrm{N}=53)$ were collected in Formosa beach $\left(20^{\circ} 17^{\prime} 44^{\prime \prime} \mathrm{S} ; 40^{\circ} 17^{\prime} 82^{\prime} \mathrm{W}\right)$ (Figure 1). This region is under the influence of nautical and harbor activities, which are potential organotin sources. After sampling, animals were taken to a field laboratory and analyzed using a non-destructive method (Fernandez et al., 2007). The shells were measured for maximum length using Vernier callipers and the animals were narcotized with $4 \% \mathrm{MgCl}_{2}$ in distilled water in 1:1 solution with local sea water. The interior of the mantle cavity was examined in each animal and the presence of penises, pre-penises and vas deferens was recorded. After examination, the majority of the animals (46) were returned to their original habitat, while seven (six imposex females and one adult male, for reference) were taken to the Malacology Laboratory of Espírito Santo Federal University for confirmatory conventional imposex analysis. They were kept under aeration with local seawater until the analysis. Animals were again narcotized and then removed from the shell and immediately examined under a dissection microscope for a detailed observation of imposex development. Penises lengths were measured with Vernier calipers, the vas deferens development was observed and the blockage of the vulva verified under a stereomicroscope. Imposex development was quantified according to Gibbs \& Bryan (1987) and Fernandez et al. (2005b) with the application of the following indexes: 1) imposex percentage in females (I\%); 2) relative penis length index (RPLI) calculated by the equation [mean length of the female penis / mean length of male penis] $\cdot 100 ; 3$ ) relative penis size index (RPSI) calculated by the equation [(mean length of the female penis $\left.)^{3} /(\text { mean length of the penis })^{3}\right] \cdot 100$; and 4) vas deferens sequence index (VDSI). 


\section{RESULTS}

Imposex was observed in females analyzed by the nondestructive method. This experiment showed 39 imposexed females (73.6\%), 5 normal females $(9.4 \%)$ and 9 males $(17.0 \%)$. By the conventional dissection approach, a reference male and six imposexed females were studied. While in this species the male show a well defined vas deferens (Figure 2), this could not be observed in the analyzed females that showed penis development. In the whole experiment, 18 females showed measurable penises (Figure 3), while 21 showed prepenises only (Figure 4). For the conventional study, mean female penis length was $6.3 \mathrm{~mm}$, while for the reference male it was $24.3 \mathrm{~mm}$. Male penises in this specie is broader and flattened than those of the imposexed females. At least in the imposex intensity observed in this area, adult imposex females could be easily distinguished from the adult males. For the 6 dissected females, RPLI value was 26.05 and RPSI value was 1.77. A VDSI value could not be determined because no vas deferens development was observed. The vulva was also easily observed in the dissected specimens, but no signs of sterility were noticed in these females.

\section{DISCUSSION}

Mesogastropods are also used as bioindicators for imposex (Stroben et al., 1995; Deutsch \& Fioroni, 1996), but they are generally less sensitive and available than neogastropods (Vishwakiran et al., 2006). Although all previous monitoring studies in Espírito Santo state were done with S. haemastoma, T. deltoidea and L. nassa, the present study demonstrated the viability of $C$. parthenopeum parthenopeum for imposex development monitoring

The animals at Formosa beach showed imposex development, presenting values for RPLI and RPSI indexes comparable with those observed for S. haemastoma from well- known contaminated areas, such as Guanabara Bay (Fernandez et al., 2002; 2005b) and Vitória harbor, Espírito Santo (unpublished data). However, the lack of observable vas deferens development makes meaningless the application of the VDSI index in this species. This is different from what was seen for other species studied in Brazil until now, which normally show a well developed vas deferens, reaching the vulva opening, with only pre-penises or very small penises developed. Most of $C$. parthenopeum parthenopeum females observed in this study showed a similar imposex development (21 with pre-penises against 18 with measurable penises), but sterility was not observed. Conversely, sterility was already registered for the neogastropods $S$. haemastoma and L. nassa in some stations in Vitória area (Costa et al., 2008). Since these two neogastropods were not found at Formosa beach, it suggests that $C$. parthenopeum parthenopeum is less sensitive to organotins contamination. In Guanabara Bay, as well as in Angra dos Reis, in Rio de Janeiro coast, S. haemastoma populations declined in areas of heavy shipping and nearby marinas (Fernandez et al., 2005b; Pinheiro et al., 2006). This suggestion is also supported by the observation that almost all imposexed females of L. nassa from Vitória area presented measurable penises (only 8 in 200 females showed pre-penises) and most $S$. haemastoma females in the area presented pre-penises (unpublished data). Further investigations are needed to elucidate the absence of neogastropods and the impact of imposex in this area, and also the relative sensitivity of $C$. parthenopeum parthenopeum, regards other local species. In spite of that, the present study demonstrated that $C$. parthenopeum parthenopeum can be used for monitoring OTs contamination.

Acknowledgements - Comissão Nacional de Pesquisa (CNPq) - CT - Hidro 39/2006 - Process n. 555407, Fundo de Apoio à Ciência e Tecno-logia Prefeitura Municipal de Vitória (FACITEC/PMV) - Process n. 035/2006, Fundação de Apoio à Ciência e Tecnologia do Espírito Santo (FAPES) Process n. 35521724/2006 and Proficiency Program of UERJ/ FAPERJ.

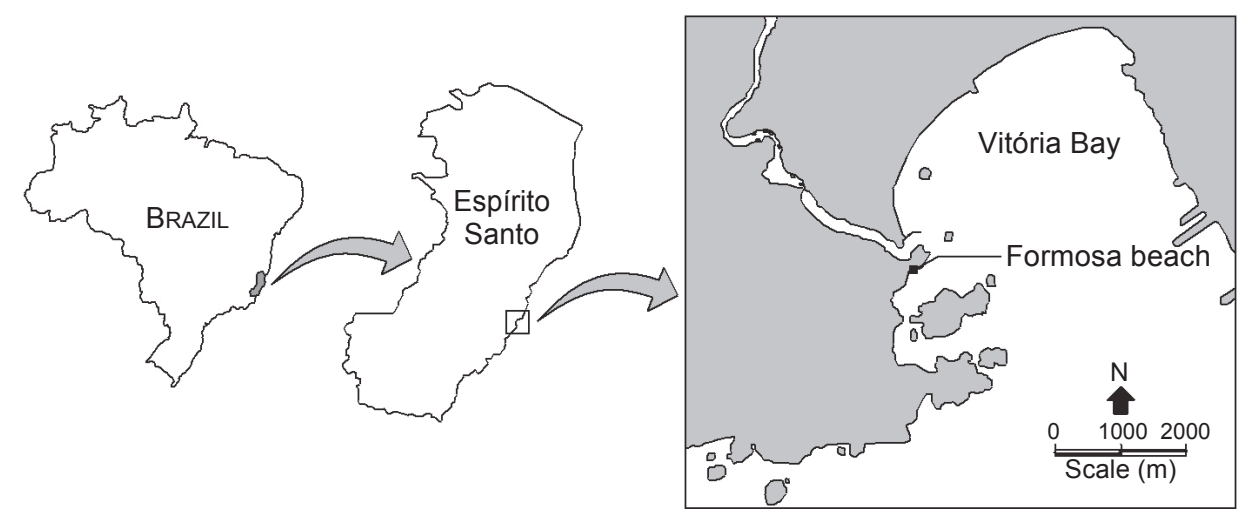

Figure 1 - Location of the study area on the Espírito Santo coast. 


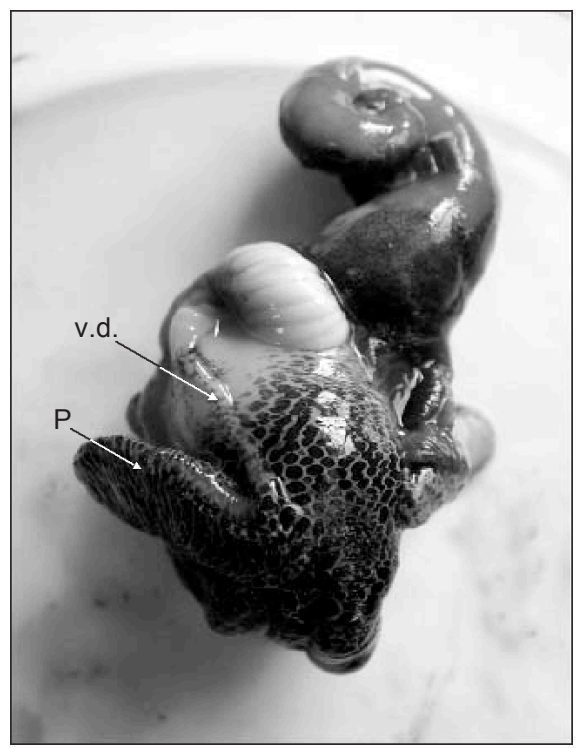

Figure 2 - Male of Cymatium parthenopeum parthenopeum showing penis (P) and vas deferens (v.d.).

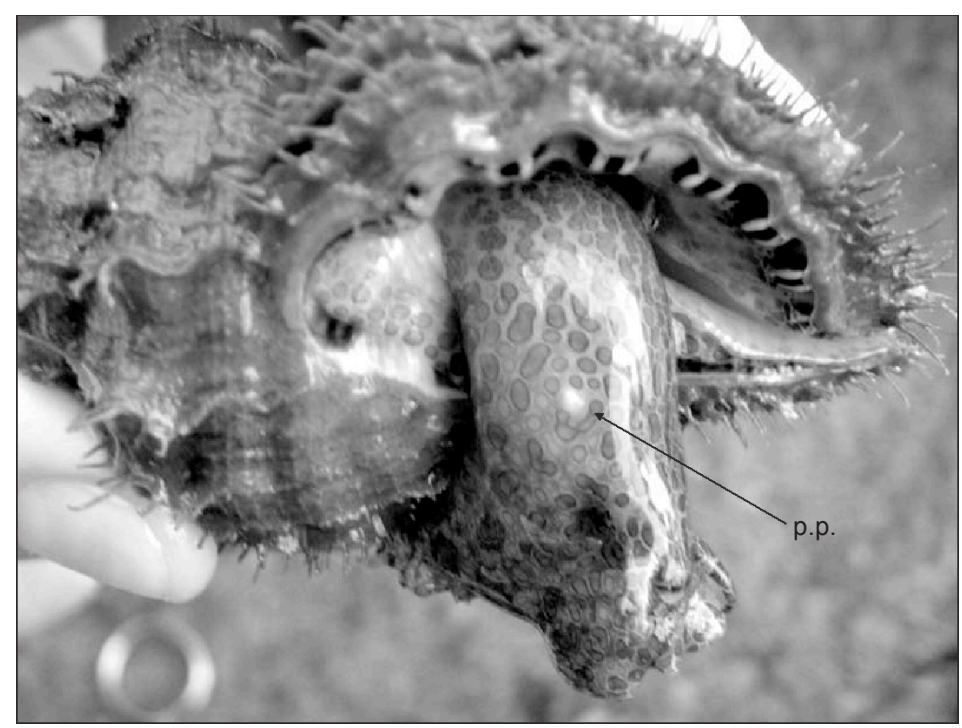

Figure 3 - Imposexed female of Cymatium parthenopeum parthenopeum with pre-penis (p.p.).

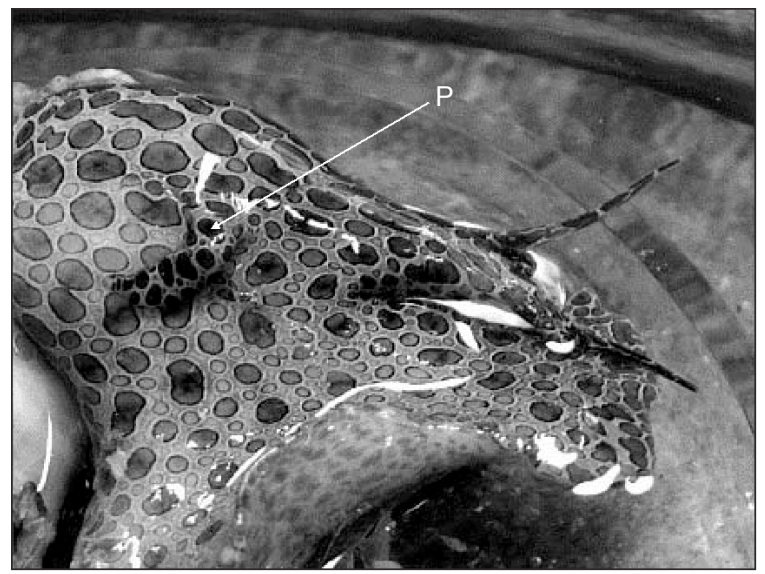

Figure 4 - Imposexed female of Cymatium parthenopeum parthenopeum with penis (P). 


\section{REFERENCES}

ALZIEU, C., 1998, Tributyltin: case study of a chronic contaminant in the coastal environment. Ocean. Coast. Manage., 40: 23-36.

BENNETT, R. F., 1996, Industrial manufacture and applications of tributyltin compounds. In: S. J. de Mora (ed.), Tributyltin: case study of an environmental contaminant. Cambridge University Press, Cambridge, pp. 21-61.

CAETANO, C. H. S. \& ABSALÃO, R. S., 2002, Imposex in Olivancillaria vesica vesica (Gmelin) (Gastropoda, Olividae) from a Southeasterns Brazilian sand beach. Revta. Bras. Zool., 19: 215-218.

CAMillo, E., QUADros, J., CASTRO, I. B. \& FERNANDEZ, M. A., 2004, Imposex in Thais (Stramonita) rustica (Mollusca: Neogastropoda) (Lamarck, 1822) as an indicator of organotin compounds pollution at Maceió coast (Northeastern Brazil). Brazil. J. Ocean., 52: 101-105.

CASTRO, I. B., 2005, Estudo do imposex em muricídeos do gênero Stramonita (Mollusca:Gastropoda) no nordeste do Brasil. Tese de Mestrado, Instituto de Ciências do Mar, UFCE, 135 p.

CASTro, I. B., MEIRELleS, C. A., MATTHEWS-CASCON, H. \& FERNANDEZ, M. A., 2004, Thais (Stramonita) rustica (Lamarck, 1822) (Mollusca: Gastropoda: Thaididae), a potential bioindicator of contamination by organotin Northeast Brazil, Brazil. J. Ocean., 52: 555.

CASTRO, I. B.; LIMA, A. F. A.; BRAGA, A. R. C. \& ROCHABARREIRA, C. A., 2007, Imposex in two Muricid species (Mollusca: Gastropoda) from the Northeastern Brazilian Coast. J. Braz. Soc. Ecotoxicol., 2: 81-91.

CHAMP, M. A. \& SELIGMAN, P. F., 1996, An introduction to organotin compounds and their use in antifouling coatings. In M. A. Champ \& P. F. Seligman (eds.), Organotin environmental fate and effects. Chapman \& Hall, London, pp. 1-25.

CHIEN, L. C., HUNG, T. C. \& CHAOANG, K. Y., 2002, Daily intake of TBT, $\mathrm{Cu}, \mathrm{Zn}, \mathrm{Cd}$ e As, for fishrmen in Taiwan. Sci. Total Environ., 285: $117-185$.

COSTA, M. B., FERnANDEZ, M. A., BARBIERO, D. C., MELO, F. T. V., OTEGUI, M. B. P. \& FERREIRA, B. S., 2008, First record of imposex in Thais deltoidea (Lamarck, 1822) (Mollusca, Gastropoda, Thaididae) in Vitória, ES, Brazil. Brazil. J. Ocean. 56: 145-148.

DEUTSCH, U. \& FIORONI, P., 1996, Effects of tributyltin (TBT) and testosterone on the female genital system in the mesogastropod Littorina littorea (Prosobranchia). Helgol. Meeres., 50: 105-115.

FERNANDEZ, M. A., 2001, Compostos orgânicos de estanho na Baía de Guanabara: sua distribuição e possíveis impactos. Tese de Dou-torado, Departamento de Química, Pontifícia Universidade Católica do Rio de Janeiro, Rio de Janeiro, 192 p.

FERNANDEZ, M. A., LIMAVERDE, A. M., CASTRO, I. B., TERRA, A. C. \& WAGENER, A. de L., 2002, Ocurrence of imposex in Thais haemastoma: evidences of environmental contamination derived from organotion compounds in Rio de Janeiro and Fortaleza, Brasil. Publ. Heatlh. Rep., 18: 463-476.

FERNANDEZ, M. A., LIMAVERDE, A. M, SCOFIELD, A. L. \& WAGENER, A. L. R., 2005a, Preliminary evaluation of human health risks from ingestion of organotin contamined seafood in Brazil. Braz. J. Oceanogr., 53: 75-77.

FERNANDEZ, M. A., WAGENER, A. L. R., LIMAVERDE, A., SCOFIELD, A. L., PINHEIRO F. M. \& RODRIGUES E., 2005b, Imposex and surface sediment speciation: A combined approach to evaluate organotin contamination in Guanabara Bay, Rio de Janeiro, Brazil. Mar. Environ. Res., 59: 435-452.

FERNANDEZ, M. A., PINHEIRO, F. M., QUADROS, J. P. \& CAMILO, E., 2007, An easy, non-destructive, probabilistic method to evaluate the imposex response of gastropod populations. Mar. Environ. Res., 63: 41-54.
FENT, K., 1996, Ecotoxicology of organotin compounds. Crit. Rev. Toxicol., 26: 1-117.

GIBBS, P. E. \& BRYAN, G. M., 1986, Reprodutive failure in populations of the dog-whelk Nucella lapillus, ceased by imposex induced by tributyltin from antifouling paints. J. Mar. Biol. Assoc. UK, 66: 767-777.

GIBBS, P. E. \& BRYAN, G.W., 1987, TBT paints and demise of the dogwhelk Nucella lapillus (Gastropoda). J. Mar. Biol. Assoc. UK, 68: 1482-1487.

GIBBS, P. E. \& BRYAN, G. W., 1994, Biomonitoring of tributyltin (TBT) pollution using the imposex response of neogastropod molluscs. Biomonit. Coast. Waters and Estuaries, 54: 205-226.

GIBSON, C. P. \& WILSON, S. P., 2003, Imposex still evident in eastern Australia 10 years after tributyltin restrictions. Mar. Environ. Res., 55: 101-112.

GOLDBERG, E. D., 1986, TBT: an environmental dilemma. Environment, $28: 17-44$.

GOODING, M., GALLARDO, C., LEBLANC, G., 1999, Imposex in three marine Gastropod species in Chile and potential impact on Muriciculture. Mar. Poll. Bull., 38: 1227-1231.

GURUGE, K. S., IWATA, H., TANAKA, H. E. \& TANABE, S., 1997, Butyltin accumulation in the liver and kidney of seabirds. Mar. Environ. Res., 44: 191-199.

LE, T. H. L., TAKAHASHI, S., SAEKI, K., NAKATANI, N., TANABE, S., MIYAZAKI, N. \& FUJISE, Y., 1999, High percentage of butyltin residues in total tin in the livers of cetaceans from Japanese coastal waters. Environ. Sci. \& Tech., 33: 1781-1786.

MATTHIESSEN, P. \& GIBBS, P. E., 1998, Critical appraisal of the evidence for tributyltin-mediated endocrine disruption in mollusks. Environ. Toxic. Chem., 17: 37-43.

MENSINK, B. P., KRALT, H., VETHAAK, A. D., TEN HALLERS-TJABBES, C., KOEMAN, J. H., VAN HATTUN, B. \& AND BOON, J. P., 2002, Imposex induction in laboratory reared juvenile Buccinun undatun by Tributyltin (TBT). Environ. Toxicol. Pharmacol., 11: 49-65.

PINHEIRO, F. M., FERNANDEZ, M. A., FRAGOSO, M. R, QUADROS, J. P, CAMILlO Jr, E. \& SANTOS, F. A. 2006, Assessing the impacts of organotin compounds in Ilha Grande Bay (Rio de Janeiro, Brazil); imposex and a multiple source dispersion model. J. Coast. Res., SI 39: 1383-1388.

QUADROS, J. P., 2004, Uma indicação da poluição por compostos orgânicos de estanho (COE) entre Angra dos Reis, Ilha Grande e a Baía de Sepetiba através do desenvolvimento do imposex em Stramonita haemastoma. Monografia de graduação, Departamento de Oceanografia, UERJ, $47 \mathrm{p}$.

RIOS, E., 1994, Seashells of Brazil. 2 ed. Fundação Universidade do Rio Grande, Rio Grande, RS, 492 p.

SHI, H. H., HUANG, C. J., ZHU, S. X., YU, X. J. \& XIE, W. Y., 2005 , Generalized system of imposex and reproductive failure in female gastropods of coastal waters in mainland China. Mar. Ecol. Prog. Ser., 304: 179-189.

STROBEN, E., SCHULTE-OEHLMANN, U., FIORONI, P., OEHLMANN, J. A., 1995, Comparative method for easy assessment of coastal TBT pollution by the degree of imposex in prosobranch species. Haliotis. 24: 1-12.

TANABE, S. 1999, Butyltin contamination in marine mammals $-A$ Review. Mar. Poll. Bull., 39: 62-72.

VISHWAKIRAN, Y.; ANIL, A. C.; VENKAT, K. \& SAWANT, S. S., 2006, Gyrineum natator: A potencial indicator of imposex along the Indian coast. Chemosphere. 62: 1718-1725.

WWF. 2006, Tributyltin pollution on a global scale. An overview of relevant and recent research: impacts and issues. Report to Dr. Simon Walmsley, WWF/UK, 48p.

www.imo.org., consulted in Feb. 2, 2008. 